\title{
Single-nucleotide polymorphisms and copy number variations of the FCGR2A and FCGR3A genes in healthy Japanese subjects
}

\author{
HIROYUKI MORIYA $^{1}$, KATSUHIKO SAITO ${ }^{1,2}$, NUALA HELSBY ${ }^{3}$, NAOMI HAYASHI ${ }^{1}$, SHIGEKAZU SUGINO ${ }^{4}$, \\ MICHIAKI YAMAKAGE ${ }^{4}$, TAKERU SAWAGUCHI ${ }^{5}$, MASAHIKO TAKASAKI $^{5}$, \\ MASATO TAKAHASHI $^{6}$ and NAHOKO KUROSAWA ${ }^{1}$
}

\begin{abstract}
${ }^{1}$ Department of Pharmacy, Hokkaido Pharmaceutical University School of Pharmacy, Otaru, Hokkaido 047-0264; ${ }^{2}$ Department of Pharmacy, Sapporo Hokuyu Hospital, Sapporo, Hokkaido 003-0006, Japan;

${ }^{3}$ Department of Molecular Medicine and Pathology, Faculty of Medical and Health Sciences, University of Auckland, Auckland 1142, New Zealand; ${ }^{4}$ Department of Anesthesiology, Sapporo Medical University School of Medicine, Sapporo, Hokkaido 060-8543; Departments of ${ }^{5}$ Pharmacy and ${ }^{6}$ Breast Surgery, National Hospital Organization Hokkaido Cancer Center, Sapporo, Hokkaido 003-0804, Japan
\end{abstract}

Received October 24, 2013; Accepted November 18, 2013

DOI: $10.3892 /$ br.2013.210

\begin{abstract}
Fc $\gamma$ RII and $\mathrm{Fc} \gamma \mathrm{RIII}$ are low-affinity $\mathrm{Fc} \gamma$ receptors that are encoded by the FCGR2A and FCGR3A genes, respectively. These genes contain functional single-nucleotide polymorphisms (SNPs), which alter the binding affinities of these receptors for the $\gamma$ chain of the Fc fragment of immunoglobulin G. The known SNPs in FCGR2A and FCGR3A are $\operatorname{rs} 1801274(\mathrm{~A}>\mathrm{G} ; \mathrm{H} 131 \mathrm{R})$ and $\mathrm{rs396991}(\mathrm{T}>\mathrm{G} ; \mathrm{F} 158 \mathrm{~V})$, respectively. It is also known that there are copy number variations (CNVs) in the genetic locus (1q23) where FCGR2A and $F C G R 3 A$ are located. However, the frequencies of these SNPs and CNVs have not been determined in the Japanese population. The aim of this study was to investigate SNPs and CNVs in FCGR2A and FCGR3A among 113 healthy individuals. The SNPs and CNVs in FCGR2A and FCGR3A were determined using the TaqMan ${ }^{\circledR}$ SNP Genotyping and the TaqMan ${ }^{\circledR}$ Copy Number assays. Our results revealed that the incidence of FCGR2A (rs1801274) genotypes were as follows: A/A, 69.9\%; $\mathrm{A} / \mathrm{G}, 29.2 \%$; and $\mathrm{G} / \mathrm{G}, 0.9 \%$. The incidence of the $F C G R 3 A$ (rs396991) genotypes were as follows: T/T, 56.7\%; T/G, 38.9\%; and $\mathrm{G} / \mathrm{G}, 4.4 \%$ ). No CNVs were detected for FCGR2A. To the best of our knowledge, this finding has not been previously reported in the Japanese population. By contrast, CNVs were observed in FCGR3A (3 subjects were found to harbour a gene deletion and 5 subjects had 3 copies of the gene). Using simple commercially available assays we were able to confirm
\end{abstract}

Correspondence to: Dr Katsuhiko Saito, Department of Pharmacy, Sapporo Hokuyu Hospital, 5-1 Higashi-Sapporo 6-jo 6-chome, Shiroishi-ku, Sapporo, Hokkaido 003-0006, Japan

E-mail: hpu.101.labo@gmail.com

Key words: Fc $\gamma$ receptor, FCGR2A, FCGR3A, single-nucleotide polymorphism, copy number variation previous findings regarding FCGR2A and FCGR3A alleles and $\mathrm{CNVs}$. These assays may provide a basis for the investigation of the role of these genes in the efficacy of antibody-based drugs, such as trastuzumab and rituximab, in Japanese subjects.

\section{Introduction}

$\mathrm{Fc} \gamma$ receptors $(\mathrm{Fc} \gamma \mathrm{Rs})$ bind specifically to the $\gamma$ chain of the Fc fragment of immunoglobulin $\mathrm{G}(\mathrm{IgG})$ and are located on the surface of immune cells, such as monocytes, macrophages and natural killer cells. Fc $\gamma$ Rs are directly involved in the function of these immune cells and regulate immune responses. There are 3 subtypes of Fc $\gamma$ Rs, i.e., Fc $\gamma$ RI, Fc $\gamma$ RII and Fc $\gamma$ RIII, which are highly homologous to one another. Fc $\gamma$ RI binds to $\mathrm{IgG}$ with high-affinity, whereas Fc $\gamma \mathrm{RII}$ and Fc $\gamma \mathrm{RIII}$ are low-affinity receptors for $\operatorname{IgG}(1,2)$. Each of these receptors has multiple isoforms. Among these isoforms, Fc $\gamma$ RIIa and Fc $\gamma$ RIIIa are encoded by the FCGR $2 A$ and FCGR3A genes, respectively. It is also known that there are non-synonymous single-nucleotide polymorphisms (SNPs) for these genes, including rs1801274 (A>G; H131R) for FCGR2A and rs396991 (T>G; F158V) for FCGR3A (3-7). These SNPs encode for functional receptors and the receptor encoded by each variant gene has a distinct binding affinity for the Fc fragment of an antibody. It was previously reported that the affinity of Fc $\gamma$ RIIa with the H131 variant is higher compared to that with the R131 variant and the affinity of Fc $\gamma$ RIIIa with the V158 variant is higher compared to that with the F158 variant $(4,8,9)$. It was also reported that these SNPs are associated with a risk for the development of autoimmune diseases, such as systemic lupus erythematosus (SLE) (10-12), and may also be involved in individual differences in the efficacy of antibody-based drugs, such as rituximab (13-16), trastuzumab $(17,18)$ and cetuximab (19-21). However, there is currently no consensus on these findings and available information regarding the frequency of these SNPs in the Japanese population has not been adequately investigated (7). 
In addition, it was recently demonstrated that copy number variations (CNVs) may also be involved in disease susceptibility (22-24). It is known that there are CNVs at the genetic locus (1q23) where FCGR2A and FCGR3A are located $(6,25-28)$. It was also reported that CNVs are a risk factor for the development of autoimmune diseases, such as SLE $(9,26,29,30)$. However, compared with SNPs for these genes, the involvement of CNVs in FCGR2A and FCGR3A and the risk of development of autoimmune diseases has not been adequately investigated. Although CNVs in FCGR3A have been reported previoulsy, there is no available information regarding the frequency of CNVs in FCGR $2 A$ in the Japanese population.

The aim of this study was to investigate the prevalence of SNPs and CNVs in FCGR2A and FCGR3A in the Japanese population, in order to aid the future diagnosis and treatment of autoimmune diseases and the prediction of antibody-based drug efficacy.

\section{Materials and methods}

Subjects. A total of 113 healthy Japanese volunteers (59 males and 54 females), aged 21-41 years and residing in the city of Sapporo and neighboring areas, were enrolled in this study. The study protocol was approved by the Institutional Review Board of the National Hospital Organization Hokkaido Cancer Center and written informed consent was obtained from all participating subjects.

Genomic DNA isolation. Genomic DNA was isolated from peripheral blood anticoagulated with $\mathrm{K}_{2}$-EDTA using a Puregene ${ }^{\circledR}$ DNA Isolation kit (Qiagen, Hilden, Germany) according to the manufacturer's protocol. The quantity and quality of the extracted genomic DNA were evaluated using a NanoDrop ${ }^{\mathrm{TM}}$ ND-1000 spectrophotometer (Thermo Fisher Scientific, Inc., Wilmington, DE, USA) and electrophoresis with an ethidium bromide-agarose gel, respectively.

Genotyping of SNPs. The genotypes of rs1801274 (A>G) in the FCGR2A gene and rs396991 (T>G) in the FCGR3A gene were determined by the TaqMan ${ }^{\circledR}$ SNP Genotyping assay (Life Technologies, Carlsbad, CA, USA). The assay IDs were c_9077561_20 for rs1801274 and c_25815666_10 for rs396991. The polymerase chain reaction (PCR) mixture contained $5 \mu \mathrm{l}$ of $2 \mathrm{X}$ TaqMan Fast Universal PCR Master mix (Life Technologies) for rs1801274 and $5 \mu$ l of 2X TaqMan Universal PCR Master mix (Life Technologies) for rs396991. Both reactions used $\sim 100 \mathrm{ng}$ of genomic DNA and $0.25 \mu \mathrm{l}$ of $40 \mathrm{X}$ TaqMan SNP Genotyping assay, with the final volume adjusted to $10 \mu \mathrm{l}$ using sterile purified water. The cycling conditions were as follows: rs1801274 was pre-warmed at $60^{\circ} \mathrm{C}$ for $1 \mathrm{~min}$, followed by AmpliTaq Gold activation (hot start) at $95^{\circ} \mathrm{C}$ for $20 \mathrm{sec}$, denaturation at $95^{\circ} \mathrm{C}$ for $3 \mathrm{sec}$, annealing/extension at $60^{\circ} \mathrm{C}$ for $30 \mathrm{sec}$, repeated for 40 cycles, followed by a post-read at $60^{\circ} \mathrm{C}$ for $1 \mathrm{~min}$; rs 396991 was pre-warmed at $60^{\circ} \mathrm{C}$ for $1 \mathrm{~min}$, followed by uracil-DNA glycosylase activation at $50^{\circ} \mathrm{C}$ for $2 \mathrm{~min}$, AmpliTaq Gold activation (hot start) at $95^{\circ} \mathrm{C}$ for $10 \mathrm{~min}$, denaturation at $95^{\circ} \mathrm{C}$ for $15 \mathrm{sec}$, annealing/extension at $60^{\circ} \mathrm{C}$ for $1 \mathrm{~min}$, repeated for 40 cycles and followed by a post-read at $60^{\circ} \mathrm{C}$ for $1 \mathrm{~min}$.
Table I. FCGR2A (rs1801274; A>G) and FCGR3A (rs396991; $\mathrm{T}>\mathrm{G}$ ) genotypes of the subjects included in this study.

\begin{tabular}{lccc}
\hline Gene & SNP & Genotype & No. of subjects (\%) \\
\hline FCGR2A & rs1801274 & $\mathrm{A} / \mathrm{A}$ & $79(69.9)$ \\
& & $\mathrm{A} / \mathrm{G}$ & $33(29.2)$ \\
FCGR3A & $\mathrm{rs} 396991$ & $\mathrm{G} / \mathrm{G}$ & $1(0.9)$ \\
& & $\mathrm{T} / \mathrm{T}$ & $64(56.7)$ \\
& & $\mathrm{T} / \mathrm{G}$ & $44(38.9)$ \\
& & $\mathrm{G} / \mathrm{G}$ & $5(4.4)$ \\
\hline
\end{tabular}

SNP, single-nucleotide polymorphism.

Following amplification of the DNA templates using the ABI PRISM ${ }^{\circledR} 7500$ Fast Real-Time PCR system (Life Technologies), allele determinations were performed with endpoint fluorescence intensity measurements, using the 7500 System software (Life Technologies).

Determination of $C N V s$. For the determination of CNVs at the FCGR2A and FCGR3A loci, the TaqMan Copy Number assay (Life Technologies) was used. The assay IDs were Hs00103511_cn for FCGR2A (exon 1-intron 1) and Hs00139300_cn for FCGR3A (exon 2). In addition, TaqMan Copy Number Reference assay RNase P (Life Technologies) was used. The PCR amplifications were performed in a reaction volume of $20 \mu \mathrm{l}$, containing $10 \mu \mathrm{l}$ of $2 \mathrm{X}$ TaqMan Universal PCR Master mix, $1.0 \mu \mathrm{l}$ of 20X TaqMan Copy Number assay, $1.0 \mu \mathrm{l}$ of 20X TaqMan Copy Number Reference assay and 20 ng of template DNA. The cycling conditions were as follows: enzyme activation (hot start) at $95^{\circ} \mathrm{C}$ for $20 \mathrm{sec}$, followed by denaturation at $95^{\circ} \mathrm{C}$ for $15 \mathrm{sec}$, annealing/extension at $60^{\circ} \mathrm{C}$ for $1 \mathrm{~min}$ and repeated for 40 cycles. The copy numbers were determined using CopyCaller ${ }^{\mathrm{TM}}$ software (Life Technologies) following amplification of the DNA templates using the ABI PRISM $^{\circledR} 7500$ Fast Real-Time PCR system and measuring fluorescence intensity at the endpoint. To obtain an accurate copy number, 4 different DNA templates were used for each sample. At least 7 samples were simultaneously analyzed to determine the copy number using CopyCaller ${ }^{\mathrm{TM}}$ software (Invitrogen Life Technologies, Carlsbad, CA, USA).

Statistical analysis. The Hardy-Weinberg equilibrium (HWE) test for assessing the rs1801274 and rs396991 genotype frequency among the subjects was conducted using PowerMarker software, version 3.0 (31) and a HWE calculator including analysis for ascertainment bias software (32). The allele and CNV frequencies were compared with previously published data from healthy individuals using the Fisher's exact test with SPSS Statistics software, version 21 (IBM Japan, Ltd., Tokyo, Japan). A two-tailed $\mathrm{P}<0.05$ was considered to indicate a statistically significant difference.

\section{Results}

Genotype determinations and comparisons of allele frequencies with published data on healthy individuals. The genotype 
Table II. Ethnic differences in the allele frequency of FCGR2A rs1801274 (A>G) in healthy subjects.

\begin{tabular}{|c|c|c|c|c|c|c|}
\hline \multirow[b]{2}{*}{ Study } & \multirow[b]{2}{*}{ Population } & \multirow[b]{2}{*}{ No. } & \multicolumn{2}{|c|}{ Allele frequency } & \multirow[b]{2}{*}{ P-value ${ }^{a}$} & \multirow[b]{2}{*}{ Refs. } \\
\hline & & & A & G & & \\
\hline The present study & Japanese & 113 & 0.845 & 0.155 & - & \\
\hline \multirow[t]{3}{*}{ Iwasaki et al } & Japanese & 403 & 0.800 & 0.200 & 0.128 & \multirow[t]{3}{*}{ (7) } \\
\hline & Japanese Brazilians & 80 & 0.806 & 0.194 & 0.318 & \\
\hline & Non-Japanese Brazilians & 386 & 0.469 & 0.531 & $<0.0001$ & \\
\hline Breunis et al & Northern-European & 100 & 0.540 & 0.460 & $<0.0001$ & (6) \\
\hline \multirow[t]{2}{*}{ Van Den Berg et al } & Ethiopians & 77 & 0.470 & 0.530 & $<0.0001$ & \multirow[t]{2}{*}{ (5) } \\
\hline & Norwegians & 86 & 0.420 & 0.580 & $<0.0001$ & \\
\hline \multirow[t]{2}{*}{ Reilly et al } & African American & 50 & 0.440 & 0.560 & $<0.0001$ & \multirow[t]{2}{*}{ (3) } \\
\hline & Caucasian American & 47 & 0.540 & 0.460 & $<0.0001$ & \\
\hline
\end{tabular}

${ }^{a}$ The Fisher's exact test was used to determine the differences between the allele frequency in this study and previously published results.

Table III. Ethnic differences in the allele frequency of FCGR3A rs396991 (T>G) in healthy subjects.

\begin{tabular}{|c|c|c|c|c|c|c|}
\hline \multirow[b]{2}{*}{ Study } & \multirow[b]{2}{*}{ Population } & \multirow[b]{2}{*}{ No. } & \multicolumn{2}{|c|}{ Allele frequency } & \multirow[b]{2}{*}{ P-value } & \multirow[b]{2}{*}{ Refs. } \\
\hline & & & $\mathrm{T}$ & $\mathrm{G}$ & & \\
\hline The present study & Japanese & 113 & 0.761 & 0.239 & - & \\
\hline Iwasaki et al & $\begin{array}{l}\text { Japanese } \\
\text { Japanese Brazilians } \\
\text { Non-Japanese Brazilians }\end{array}$ & $\begin{array}{c}403 \\
80 \\
386\end{array}$ & $\begin{array}{l}0.754 \\
0.713 \\
0.715\end{array}$ & $\begin{array}{l}0.246 \\
0.287 \\
0.285\end{array}$ & $\begin{array}{l}0.824 \\
0.300 \\
0.177\end{array}$ & (7) \\
\hline Breunis et al & Northern-European & 100 & 0.710 & 0.290 & 0.232 & (6) \\
\hline Van Den Berg et al & $\begin{array}{l}\text { Ethiopians } \\
\text { Norwegians }\end{array}$ & $\begin{array}{l}77 \\
86\end{array}$ & $\begin{array}{l}0.540 \\
0.660\end{array}$ & $\begin{array}{l}0.460 \\
0.340\end{array}$ & $\begin{array}{c}<0.0001 \\
0.031\end{array}$ & (5) \\
\hline
\end{tabular}

${ }^{a}$ The Fisher's exact test was used to determine the differences between the allele frequency in this study and other previously published results.

distributions for rs1801274 of FCGR2A and rs396991 of FCGR3A obtained in this study are presented in Table I. Divergence from the HWE was not observed for either SNP.

Comparisons of the frequencies for each SNP allele with previously published data are shown in Table II for rs1801274 and in Table III for rs396991. The minor allele frequency (MAF) for rs1801274 obtained in this study (0.155) was significantly lower among Japanese individuals compared to that among other ethnic groups (Table II). The MAF for rs396991 (0.239) was marginally different from that for rs1801274 (0.155). These frequencies were not significantly different from those reported for other Japanese populations. However, the allele frequencies for rs396991 obtained in this study for Japanese subjects were significantly different from those observed in Ethiopians and Norwegians (Table III). In particular, the $\mathrm{T}$ allele frequency among Japanese was higher compared to that among Ethiopians and Norwegians.

CNV determination and comparisons of CNV frequencies with published data on healthy individuals. The CNVs for FCGR $2 A$ and FCGR3A from this study are presented in
Table IV. There was no CNV detectable for FCGR2A, as all subjects tested had 2 copies of this gene.

However, with regard to FCGR $3 A, 5$ subjects had 3 copies of this gene and 3 subjects had a single copy (gene deletion). The associations between CNVs in FCGR3A and the rs396991 genotypes were as follows: 3 subjects with a single copy of FCGR $3 A$ had the T/T genotype and of the 5 subjects with 3 gene copies, 1 had the T/T and 4 had the T/G genotype. Comparisons between the CNVs in FCGR3A from this study and those from previously published studies are shown in Table V. There were no significant differences between our results and those of previously published studies.

\section{Discussion}

In this study, the MAF for rs1801274 (A>G, H131R) of FCGR $2 A$ was 0.155 and only 1 subject $(0.9 \%)$ had the $\mathrm{G} / \mathrm{G}$ genotype. A previous study indicated that the MAF of FCGR2A among Japanese and Japanese-Brazilians was 0.200 and 0.194, respectively (7). Therefore, the SNP frequency for this minor allele appears to be between $0.15-0.2$ in the 
Table IV. Number of copy number variations in FCGR2A and FCGR3A in this study.

\begin{tabular}{lcccccc}
\hline & & \multicolumn{4}{c}{ Copy number variation $(\%)$} \\
\cline { 3 - 7 } Gene & TaqMan ${ }^{\circledR}$ Copy Number assay ID & 0 copies & 1 copy & 2 copies & 3 copies & 4 copies \\
\hline FCGR2A & Hs00103511_cn & 0 & 0 & $113(100)$ & 0 & 0 \\
FCGR3A & Hs00139300_cn & 0 & $3(2.7)$ & $105(92.9)$ & $5(4.4)$ & 0 \\
\hline
\end{tabular}

Table V. Ethnic differences in the frequency of copy number variation in FCGR3A in healthy subjects.

\begin{tabular}{|c|c|c|c|c|c|c|c|c|}
\hline \multirow[b]{2}{*}{ Study } & \multirow[b]{2}{*}{ Population } & \multirow[b]{2}{*}{ No. } & \multicolumn{4}{|c|}{ Copy number variation frequency } & \multirow[b]{2}{*}{ P-value } & \multirow[b]{2}{*}{ Refs. } \\
\hline & & & 1 copy & 2 copies & 3 copies & 4 copies & & \\
\hline The present study & Japanese & 113 & 0.027 & 0.929 & 0.044 & 0 & - & \\
\hline \multirow[t]{4}{*}{ Hollox et al } & Japanese & 32 & 0 & 0.875 & 0.094 & 0.031 & 0.301 & (25) \\
\hline & Chinese & 32 & 0.031 & 0.813 & 0.156 & 0 & 0.082 & \\
\hline & Yoruba & 35 & 0.029 & 0.943 & 0.029 & 0 & 1 & \\
\hline & Europeans & 110 & 0.027 & 0.891 & 0.082 & 0 & 0.356 & \\
\hline Breunis et al & Northern-Europeans & 129 & 0.016 & 0.946 & 0.039 & 0 & 0.606 & (26) \\
\hline Zhou et al & Han Chinese & 146 & 0.041 & 0.877 & 0.075 & 0 & 0.289 & (27) \\
\hline
\end{tabular}

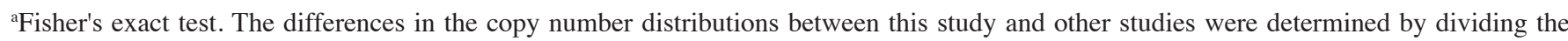
subjects into 2 groups: group A with 2 gene copies and group B with copy numbers other than 2 .

Japanese population. The rs1801274 allele frequency among the Japanese subjects in this study was significantly different from those previously reported among Europeans (3-6) and Africans $(3,4)$. Therefore, there are ethnic differences in rs1801274 SNP frequency. The MAF for $\operatorname{rs396991}(\mathrm{T}>\mathrm{G}$, $\mathrm{F} 158 \mathrm{~V})$ of $F C G R 3 A$ was previously reported to be $0.2-0.3$ among Japanese individuals (7). We confirmed this frequency in a separate population. Therefore, the prevalence of this SNP frequency was found to be marginally higher compared with that of FCGR2A rs1801274. The MAF of rs36991 was found to be significantly lower in Japanese compared with that in Ethiopians $(\mathrm{P}<0.0001)$ and marginally lower compared with that observed in Norwegians ( $\mathrm{P}=0.031)$ (4). Since rs1801274 and rs396991 are both functional SNPs, it may be predicted that the affinities of Fc $\gamma$ II a and Fc $\gamma$ IIIIa for antibodies may display ethnic variation.

No CNVs were detected for FCGR2A. To the best of our knowledge, this was the first study to assess CNVs of this gene in Japanese individuals. However, Breunis et al (26) also failed to detect any CNVs in FCGR2A among healthy European subjects, as well as among patients with diseases such as idiopathic thrombocytopenia, Kawasaki disease, or rheumatoid arthritis. By contrast, CNVs in FCGR3A were identified [ 3 subjects with a gene deletion (single copy) and 5 subjects with 3 gene copies]. This finding confirmed the previously observed presence of CNVs in FCGR3A (25). Unlike that previous small study, we did not identify any individuals with 4 gene copies; however, this may be due to the low frequency of this event. We observed a similar incidence of FCGR3A CNVs between the subjects in this study and Chinese $(25,27)$, European $(25,26)$ and African $(25,26)$ subjects. Therefore, it appears that CNVs in FCGR $3 A$ are a common finding across different ethnic groups. Changes in gene dosage caused by CNVs may result in individual variations of the Fc $\gamma$ RIIIa expression.

Three subjects with a single FCGR3A copy were found to have an rs396991 T/T genotype. However, their actual genotypes were considered to be T/- (T/del) when CNVs were taken into consideration. It was also predicted that the actual genotype of 1 subject was T/T/T and the 4 subjects genotyped as $\mathrm{T} / \mathrm{G}$ were either $\mathrm{T} / \mathrm{T} / \mathrm{G}$ or $\mathrm{T} / \mathrm{G} / \mathrm{G}$. Therefore, it is recommended to take CNVs for FCGR3A into consideration when evaluating the SNP genotype.

The TaqMan Copy Number assay to determine CNVs in FCGR2A and FCGR $3 A$ used a probe for FCGR2A that recognized the region between exon 1 and intron 1 and the probe for FCGR3A recognized a region of exon 2. To confirm our results, additional CNV analysis, using multiple probes that are able to recognize various regions of each gene should be considered. Additional analysis of the genotypes of FCGR2B, FCGR2C and $F C G R 3 B$, which are linked in tandem to FCGR2A and FCGR3A at 1q23, should also be considered in future studies.

Using commercially available TaqMan-based assays, we determined the incidence of SNPs and CNVs in FCGR2A and FCGR3A among healthy Japanese individuals. These assays confirmed data previously reported by studies that utilized more complex methods, such as multiplex ligation-dependent probe amplification (26). However, a large-scale analysis of the entire FCGR region, using a next-generation genome sequencing, may be useful for a more detailed investigation of genetic variability of $F C G R$ in the Japanese population. 
The straightforward methods used in this study to obtain information regarding the FCGR SNPs and CNVs among Japanese subjects may allow the development of diagnostic methods and treatments for autoimmune diseases, including SLE, as well as genetic biomarker research to predict the efficacy of antibody-based drugs, such as trastuzumab and rituximab.

\section{References}

1. Galon J, Robertson MW, Galinha A, et al: Affinity of the interaction between $\mathrm{Fc}$ gamma receptor type III (Fc gammaRIII) and monomeric human IgG subclasses. Role of Fc gammaRIII glycosylation. Eur J Immunol 27: 1928-1932, 1997.

2. Maenaka K, van der Merwe PA, Stuart DI, Jones EY and Sondermann P: The human low affinity Fcgamma receptors IIa, IIb, and III bind IgG with fast kinetics and distinct thermodynamic properties. J Biol Chem 276: 44898-44904, 2001.

3. Reilly AF, Norris CF, Surrey S, Bruchak FJ, Rappaport EF, Schwartz E and McKenzie SE: Genetic diversity in human Fc receptor II for immunoglobulin G: Fc gamma receptor IIA ligand-binding polymorphism. Clin Diagn Lab Immunol 1: 640-644, 1994.

4. Koene HR, Kleijer M, Algra J, Roos D, von dem Borne AE and de Haas M: Fc gammaRIIIa-158V/F polymorphism influences the binding of IgG by natural killer cell Fc gammaRIIIa, independently of the Fc gammaRIIIa-48L/R/H phenotype. Blood 90 : 1109-1114, 1997.

5. Van Den Berg L, Myhr KM, Kluge B and Vedeler CA: Fcgamma receptor polymorphisms in populations in Ethiopia and Norway. Immunology 104: 87-91, 2001.

6. Breunis WB, van Mirre E, Bruin M, et al: Copy number variation of the activating FCGR2C gene predisposes to idiopathic thrombocytopenic purpura. Blood 111: 1029-1038, 2008

7. Iwasaki M, Shimada N, Kasuga Y, et al: Fragment c gamma receptor gene polymorphisms and breast cancer risk in case-control studies in Japanese, Japanese Brazilians, and non-Japanese Brazilians. Breast Cancer Res Treat 126: 497-505, 2011.

8. Concetti F and Napolioni V: Insights into the role of Fc gamma receptors (FcgammaRs) genetic variations in monoclonal antibody-based anti-cancer therapy. Recent Pat Anticancer Drug Discov 5: 197-204, 2010.

9. Bournazos S, Woof JM, Hart SP and Dransfield I: Functional and clinical consequences of $\mathrm{Fc}$ receptor polymorphic and copy number variants. Clin Exp Immunol 157: 244-254, 2009.

10. Song YW, Han CW, Kang SW, et al: Abnormal distribution of Fc gamma receptor type IIa polymorphisms in Korean patients with systemic lupus erythematosus. Arthritis Rheum 41: 421-426, 1998.

11. Magnusson V, Johanneson B, Lima G, et al: Both risk alleles for FcgammaRIIA and FcgammaRIIIA are susceptibility factors for SLE: a unifying hypothesis. Genes Immun 5: 130-137, 2004.

12. Cartron G, Dacheux L, Salles G, et al: Therapeutic activity of humanized anti-CD20 monoclonal antibody and polymorphism in IgG Fc receptor FcgammaRIIIa gene. Blood 99: 754-758, 2002 .

13. Weng WK and Levy R: Two immunoglobulin G fragment $\mathrm{C}$ receptor polymorphisms independently predict response to rituximab in patients with follicular lymphoma. J Clin Oncol 21: 3940-3947, 2003.

14. Hatjiharissi E, Xu L, Santos DD, et al: Increased natural killer cell expression of CD16, augmented binding and ADCC activity to rituximab among individuals expressing the Fc $\gamma \mathrm{RIIIa}-158 \mathrm{~V} / \mathrm{V}$ and V/F polymorphism. Blood 110: 2561-2564, 2007.
15. Paiva M, Marques $H$, Martins A, Ferreira $P$, Catarino $R$ and Medeiros R: FcgammaRIIa polymorphism and clinical response to rituximab in non-Hodgkin lymphoma patients. Cancer Genet Cytogenet 183: 35-40, 2008.

16. Weng WK, Negrin RS, Lavori P and Horning SJ: Immunoglobulin $\mathrm{G}$ Fc receptor FcgammaRIIIa $158 \mathrm{~V} / \mathrm{F}$ polymorphism correlates with rituximab-induced neutropenia after autologous transplantation in patients with non-Hodgkin's lymphoma. J Clin Oncol 28: 279-284, 2010.

17. Musolino A, Naldi N, Bortesi B, et al: Immunoglobulin G fragment $\mathrm{C}$ receptor polymorphisms and clinical efficacy of trastuzumab-based therapy in patients with HER-2/neu-positive metastatic breast cancer. J Clin Oncol 26: 1789-1796, 2008.

18. Tamura K, Shimizu C, Hojo T, et al: Fc $\gamma \mathrm{R} 2 \mathrm{~A}$ and $3 \mathrm{~A}$ polymorphisms predict clinical outcome of trastuzumab in both neoadjuvant and metastatic settings in patients with HER2-positive breast cancer. Ann Oncol 22: 1302-1307, 2011.

19. Zhang W, Gordon M, Schultheis AM, et al: FCGR2A and FCGR3A polymorphisms associated with clinical outcome of epidermal growth factor receptor expressing metastatic colorectal cancer patients treated with single-agent cetuximab. J Clin Oncol 25: 3712-3718, 2007.

20. Bibeau F, Lopez-Crapez E, Di Fiore F, et al: Impact of Fc $\gamma$ RIIa-Fc $\gamma$ RIIIa polymorphisms and KRAS mutations on the clinical outcome of patients with metastatic colorectal cancer treated with cetuximab plus irinotecan. J Clin Oncol 27: 1122-1129, 2009.

21. Pander J, Gelderblom H, Antonini NF, et al: Correlation of FCGR3A and EGFR germline polymorphisms with the efficacy of cetuximab in KRAS wild-type metastatic colorectal cancer. Eur J Cancer 46: 1829-1834, 2010.

22. Ionita-Laza I, Rogers AJ, Lange C, Raby BA and Lee C: Genetic association analysis of copy-number variation (CNV) in human disease pathogenesis. Genomics 93: 22-26, 2009.

23. Wain LV, Armour JA and Tobin MD: Genomic copy number variation, human health, and disease. Lancet 374: 340-350, 2009.

24. Fanciulli M, Petretto E and Aitman TJ: Gene copy number variation and common human disease. Clin Genet 77: 201-213, 2010.

25. Hollox EJ, Detering JC and Dehnugara T: An integrated approach for measuring copy number variation at the FCGR3 (CD16) locus. Hum Mutat 30: 477-484, 2009.

26. Breunis WB, van Mirre E, Geissler J, et al: Copy number variation at the FCGR locus includes FCGR3A, FCGR2C and FCGR3B but not FCGR2A and FCGR2B. Hum Mutat 30: E640-E650, 2009.

27. Zhou XJ, Lv JC, Bu DF, et al: Copy number variation of FCGR3A rather than FCGR3B and FCGR2B is associated with susceptibility to anti-GBM disease. Int Immunol 22: 45-51, 2010.

28. Niederer HA, Willcocks LC, Rayner TF, et al: Copy number, linkage disequilibrium and disease association in the FCGR locus. Hum Mol Genet 19: 3282-3294, 2010.

29. Fanciulli M, Vyse TJ and Aitman TJ: Copy number variation of Fc gamma receptor genes and disease predisposition. Cytogenet Genome Res 123: 161-168, 2008.

30. Schaschl H, Aitman TJ and Vyse TJ: Copy number variation in the human genome and its implication in autoimmunity. Clin Exp Immunol 156: 12-16, 2009.

31. Liu K and Muse SV: PowerMarker: an integrated analysis environment for genetic marker analysis. Bioinformatics 21 2128-2129, 2005.

32. Rodriguez S, Gaunt TR and Day IN: Hardy-Weinberg equilibrium testing of biological ascertainment for Mendelian randomization studies. Am J Epidemiol 169: 505-514, 2009. 